\title{
Rocky Mountain Juniper Seed Source Test in Western Kansas, U.S.
}

\author{
Wayne A. Geyer, Keith D. Lynch, and Charles J. Barden
}

\begin{abstract}
Twenty-six sources of Rocky Mountain juniper (Juniperus scopulorum Sarg.) were established as a provenance test near Colby, Kansas, U.S. in 1980. Height, diameter, survival, number of stems, crown density, branch angle, and vigor were evaluated with analysis of variance, cluster analysis, simple correlation, and regression analysis techniques. Source differences were found. Total height at 23 years ranged from 3.6 to $5.4 \mathrm{~m}$ (11.9 to $17.8 \mathrm{ft}$ ), diameter breast height (dbh) ranged from 5.6 to $10.4 \mathrm{~cm}$ (2.2 to 4.2 in), and survival from $10 \%$ to $100 \%$. Height growth was weakly related to geographic variables, but dbh was related to latitude, longitude, and elevation. Selection of fast-growing sources may begin at 5 years after field planting.
\end{abstract}

Key Words. Growth characteristics; juniper; Juniperus scopulorum; Rocky Mountain juniper; seed sources.

Rocky Mountain juniper (Juniperus scopulorum Sarg.) grows on the western edge of the Great Plains, U.S. as essentially a lower-elevation pine tree, on the upper Puget Sound basin, and on Vancouver Island, British Columbia, at or near sea level. It ranges in size from a small tree to a sprawling shrub on dry mountain sites (Harlow and Harrar 1969). Taxonomic studies have been numerous (Fassett 1944; Comer et al. 1982; Adams 1983; Schaefer 1995). Genetic variation of various major traits were determined for 10-year-old plantings, and seed-source selection zones in the Great Plains were identified by Cunningham and King (2000).

This test is part of a larger regional study initiated by the Technical Committee of the Great Plains Agricultural Council in 1973. The objectives were to determine the genetic variation of major traits and to identify the best sources of seed for windbreak applications. This article presents the portion of the study established in Colby, Kansas after 23 years of growth in the field.

\section{MATERIALS AND METHODS}

A complete description of the methodology used is found in Van Haverbeke and King (1990). Seed cones were collected from 26 trees in natural stands and windbreaks across the Great Plains (Figure 1; Table 1). Seed trees that had favorable windbreak characteristics (abundant branches, dense foliage) were selected. Seed lots were sown in the USDA Forest Service Bessey Nursery near Halsey, Nebraska, in 1977 and were outplanted at 12 test sites in 1980 . This study site is Colby, Kansas $\left(39.38^{\circ} \mathrm{N}\right.$ and $\left.101.07^{\circ} \mathrm{W}\right)$ located in the central geographic region of zones established by Van Haverbeke
(1968). Soil is from the series of Keith loam (fine-silty, mixed, mesic Aridic Haplustolls) and Richfield silty clay loam (fine, montmorillonitic, mesic Aridic Haplustolls). A randomized complete-block with five replications of fourtree, linear plots was established having 20 trees maximum for each source. A total of 520 trees were planted along with 2320 eastern redcedar (Juniperus virginia L.). Spacings in the plantation were $2.4 \mathrm{~m}(7.9 \mathrm{ft})$ within rows and $3.6 \mathrm{~m}(11.9 \mathrm{ft})$ between rows. A single row was planted on all sides as a border. Complete cultivation was maintained for 5 years. Growth evaluations were made at 5, 10, and 23 growing seasons at this site.

Statistical analyses were performed with SAS software (Statistical Analysis System; SAS Institute Inc., Cary, NC). Data were analyzed by using the analysis of variance procedure and the Duncan's means test was used for mean separation. Cluster analyses (Ward's minimum variance) were used to identify seed sources with similar performance characteristics. Variables used in those analyses were survival, total height, diameter breast height (dbh), number of stems, crown density, branch angle, vigor, latitude, longitude, and elevation. If trees had multiple stems, then only the largest was evaluated for height and diameter. Simple Pearson correlations were computed among seed sources of individual trees for each trait. The correlation of each trait with latitude and longitude was also examined. Least squares regression models of differences in latitude, longitude, and elevation between source locations and the Colby plantation were run to find the extent of geographic area from which seed may be collected to give good tree growth performance in western 


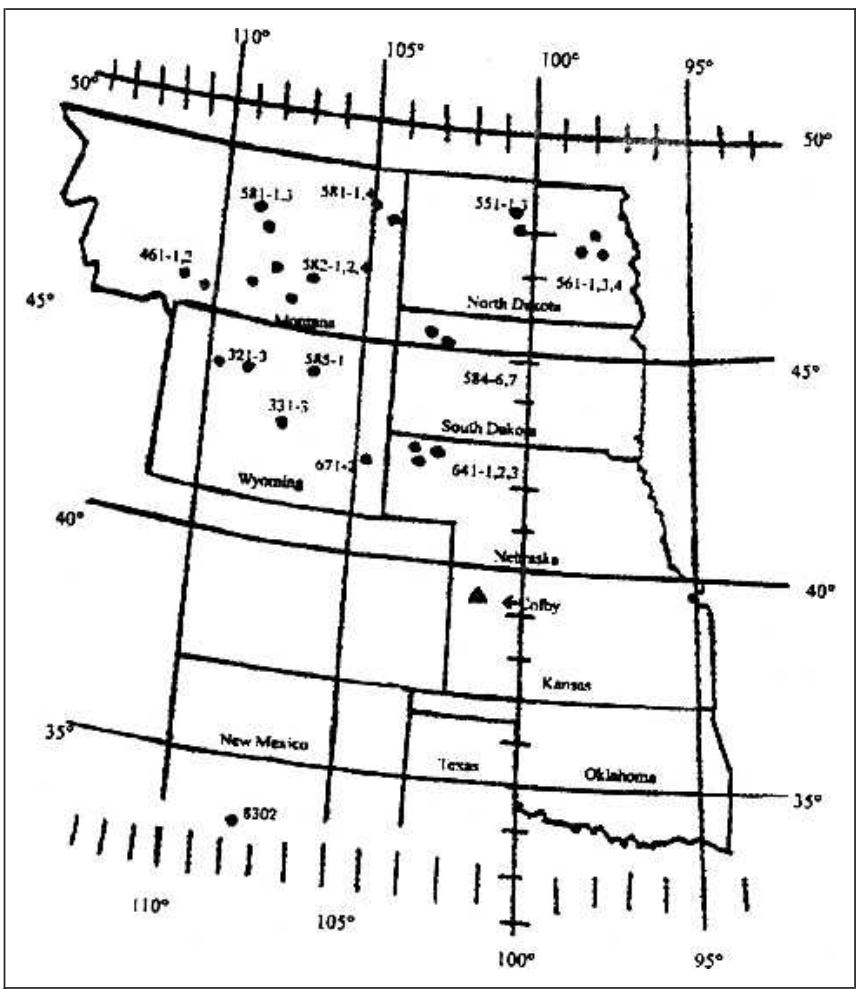

Figure 1. Seed selection zones and seed source locations in the northern Great Plains.

Kansas. To determine the reliability of early seed source selection, age/age correlations were computed for survival and height of source means at age 10 and age 23 .

\section{RESULTS}

Significant differences among seed sources existed for survival, height, dbh, number of stems, crown density, branch angle, and vigor. Each is discussed separately, but we also chose to identify more general patterns of variation by using cluster analysis.

\section{Survival}

Seed sources were significantly different (analysis of variance) in survival rates through age 23 with a range of $10 \%$ to $100 \%$ (Table 2). Total survival across the planting was $72.7 \%$. No specific patterns were indicated geographically, but the best surviving sources (70\% to $100 \%$ ) generally were from Nebraska, North Dakota, and Montana. The poorest source was from Wyoming (10\%). No trends for survival were found with latitudes, longitudes, or elevations alone.

\section{Height and Diameter}

No specific patterns were indicated geographically for either total height or $\mathrm{dbh}$. The mean height and dbh for all trees were $4.7 \mathrm{~m}(15.5 \mathrm{ft})$ and $8.6 \mathrm{~cm}(3.4 \mathrm{in})$. For all heights and diameters, the analysis of variance (Table 2) was significant for differences among sources $(P=0.01)$ with heights ranging from 3.6 to $5.4 \mathrm{~m}$ (11.9 to $17.8 \mathrm{ft})$ and dbh ranging from 5.3 to $12.4 \mathrm{~cm}$ ( 2.1 to $5 \mathrm{in})$. The tallest trees in the top $20 \%$ had high survival (at least 80\%) and were in the upper 30\%

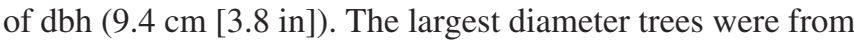
the New Mexico Source 8302, but survival was only $40 \%$. The tallest trees had better survival $(\geq 80 \%)$.

\section{Other Variables}

The mean value of the number of stems per tree for the entire planting was 2 with a range of 1.3 to 2.6 stems per tree. Only two sources showed a consistent trend toward a single-stem habit: 3312 and 3313 from northwest Wyoming. Crown density was good for all trees planted. Values ranged from medium to dense for windbreak characteristics. The branch angle was mostly between $45^{\circ}$ and $90^{\circ}$. A few sources (3312 and 3313) had a more acute angle. All surviving specimens appeared healthy after 23 years growth even under the drought regimes experienced the last few years in northwestern Kansas.

Table 1. Origin of 26 Rocky Mountain juniper seed sources planted at Colby, Kansas, in 1980.

\begin{tabular}{lllll}
\hline $\begin{array}{l}\text { Source } \\
\text { no. }\end{array}$ & $\begin{array}{l}\text { Local area } \\
\text { state }\end{array}$ & $\begin{array}{l}\text { Latitude } \\
\left({ }^{\circ} \mathrm{N}\right)\end{array}$ & $\begin{array}{l}\text { Longitude } \\
\left({ }^{\circ} \mathrm{W}\right)\end{array}$ & $\begin{array}{l}\text { Elevation } \\
(\mathrm{ft})\end{array}$ \\
\hline 3213 & Tensleep, WY & 44.10 & 107.50 & 4100 \\
3312 & Muddy Gap, WY & 42.35 & 107.46 & 4695 \\
3313 & Rawlins, WY & 41.80 & 107.22 & 7220 \\
4611 & Big Timber, MT & 45.85 & 109.96 & 4265 \\
4612 & Columbus, MT & 45.64 & 109.27 & 4100 \\
5311 & Sidney, MT & 47.73 & 104.14 & 1970 \\
5314 & Culbertson, MT & 48.16 & 104.52 & 2050 \\
5511 & Towner, ND & 48.36 & 100.41 & 1475 \\
5513 & Towner, ND & 48.36 & 100.41 & 1475 \\
5611 & Larimore, ND & 47.92 & 97.60 & 1150 \\
5613 & Larimore, ND & 47.92 & 97.60 & 1150 \\
5614 & Larimore, ND & 47.92 & 97.60 & 1150 \\
5811 & Mosby, MT & 47.00 & 107.89 & 2705 \\
5813 & Mosby, MT & 47.00 & 107.89 & 2705 \\
5821 & Billings, MT & 45.80 & 108.52 & 3280 \\
5822 & Hathaway, MT & 46.28 & 106.20 & 2790 \\
5824 & Custer, MT & 46.13 & 107.55 & 2790 \\
5826 & Sarpy, MT & 46.30 & 107.11 & 3935 \\
5846 & Reva, SD & 45.56 & 103.10 & 3115 \\
5847 & Reva, SD & 45.56 & 103.10 & 3115 \\
5851 & Johnson City, WY & 44.06 & 106.59 & 4590 \\
6411 & Chadron, NE & 42.85 & 102.99 & 3445 \\
6412 & Chadron, NE & 42.85 & 102.99 & 3445 \\
6413 & Chadron, NE & 42.85 & 102.99 & 3445 \\
6712 & Casebier, WY & 42.33 & 104.51 & 5085 \\
8302 & Ruidoso Downs, NM & 33.35 & 105.68 & 7380 \\
\hline & & & &
\end{tabular}


Table 2. Survival, height, and dbh rankings of seed sources at 23 years.

\begin{tabular}{|c|c|c|c|c|c|}
\hline Source no. & Survival (\%) & Height m (ft) & Range m (ft) & dbh cm (in) & Range cm (in) \\
\hline 5826 & 80 bcd $^{\mathrm{z}}$ & $5.4(17.7) a^{z}$ & $4.3-6.4(14.0-21.0)$ & $10.4(4.1) b c^{z}$ & $2.5-15.2(1.0-6.0)$ \\
\hline 6411 & $100 \mathrm{~d}$ & $5.3(17.4) a b$ & $4.3-6.1(14.0-20.0)$ & $9.7(3.8)$ bcd & $7.6-12.7(3.0-5.0)$ \\
\hline 6412 & 90 cd & $5.3(17.3)$ ab & $4.4-6.6(14.5-21.5)$ & $10.4(4.1)$ bc & $5.1-17.8(2.0-7.0)$ \\
\hline 5846 & $90 \mathrm{~cd}$ & $5.2(17.0)$ abcd & $4.7-5.6(15.5-18.5)$ & 9.4 (3.7) bcde & $5.1-12.7(2.0-5.0)$ \\
\hline 5513 & $40 \mathrm{abc}$ & 5.2 (16.9) abcd & $4.1-5.8(13.5-19.0)$ & $10.2(4.0) \mathrm{bc}$ & $5.1-12.7(2.0-5.0)$ \\
\hline 5813 & $90 \mathrm{~cd}$ & $5.0(16.5)$ abcdef & $4.4-5.6(14.5-18.5)$ & 8.9 (3.5) bcde & $5.1-12.7(2.0-5.0)$ \\
\hline 5613 & $90 \mathrm{~cd}$ & 5.0 (16.4) abcdef & $4.6-5.3(15.0-17.5)$ & 9.1 (3.6) bcde & $5.1-12.7(2.0-5.0)$ \\
\hline 3312 & $80 \mathrm{bcd}$ & $5.0(16.3)$ abcdef & $4.1-5.5(13.5-18.0)$ & 9.4 (3.7) bcde & $5.1-12.7(2.0-5.0)$ \\
\hline 5614 & $80 \mathrm{bcd}$ & 4.9 (16.0) abcdefg & $4.3-6.1(14.0-20.0)$ & 9.1 (3.6) bcde & $5.1-12.7(2.0-5.0)$ \\
\hline 6413 & $90 \mathrm{~cd}$ & 4.9 (16.0) bdefg & $4.3-5.9(14.0-19.5)$ & 8.6 (3.4) cdef & $5.1-12.7(2.0-5.0)$ \\
\hline 5611 & $90 \mathrm{~cd}$ & 4.8 (15.9) bcdefg & $4.3-5.3(14.0-17.5)$ & 9.7 (3.8) bcd & $5.1-15.2(2.0-6.0)$ \\
\hline 5511 & $40 \mathrm{bcd}$ & 4.7 (15.4) defgh & $4.0-5.6(13.0-18.5)$ & $8.6(3.4)$ bcde & $5.1-15.2(2.0-6.0)$ \\
\hline 3313 & $75 \mathrm{bcd}$ & 4.5 (14.8) efgh & $4.0-5.2(13.0-17.0)$ & $7.6(3.0)$ efg & $5.1-10.2(2.0-4.0)$ \\
\hline 5314 & $40 \mathrm{bcd}$ & 4.5 (14.8) fgh & $3.7-5.0(12.0-16.5)$ & $8.6(3.4)$ bcde & $7.6-12.7(3.0-5.0)$ \\
\hline 5811 & $30 \mathrm{ab}$ & 4.5 (14.6) gh & $3.4-5.2(11.0-17.0)$ & 8.1 (3.2) def & $5.1-10.2(2.0-4.0)$ \\
\hline 3213 & $85 \mathrm{~cd}$ & $4.3(14.2) \mathrm{h}$ & $3.7-5.5(12.0-18.0)$ & 6.9 (2.7) fgh & $2.5-10.2(1.0-4.0)$ \\
\hline 5851 & $40 \mathrm{abc}$ & $3.8(12.6) \mathrm{i}$ & $3.0-4.4(10.0-14.5)$ & $5.8(2.3) \mathrm{h}$ & $2.5-7.6(1.0-3.0)$ \\
\hline 4611 & $70 \mathrm{bcd}$ & $3.8(12.5) \mathrm{i}$ & $2.9-4.3(9.5-14.0)$ & $6.1(2.4) \mathrm{gh}$ & $5.1-10.2(2.0-4.0)$ \\
\hline 4612 & $90 \mathrm{~cd}$ & $3.6(11.8) \mathrm{i}$ & $3.2-4.6(10.5-15.0)$ & $5.6(2.2) \mathrm{h}$ & $2.5-7.6(1.0-3.0)$ \\
\hline
\end{tabular}

${ }^{\mathrm{z}}$ Values followed by the same letters within a column are not significantly different at the $P=0.05$. Bold type indicates tallest $20 \%$.

\section{Cluster Analysis}

Cluster analysis included all 26 sources. The analysis differentiated two, three, and four clusters with significance that was similar for survival, height, and dbh. The other variables listed were not significant and were therefore deleted in the analysis. General patterns of variation were identified by using this analysis. No distinct geographic patterns were shown in the three- and four-cluster combinations, so the two-cluster analysis was used. The height values for first and second clusters were 3.2 and $4.9 \mathrm{~m}$ (10.6 and $16.2 \mathrm{ft})$, dbh values were 6.3 and $9.9 \mathrm{~cm}$ (2.5 and 4 in), and survival rates were $66.7 \%$ and $73.9 \%$, respectively. Sources 4611,4612 , and 5851 were the shortest. These were collected from southwestern Montana and north central Wyoming. In addition, all three sources were also separated from the others in the three and four combinations.

\section{Correlations}

Age/age correlations between height and dbh were particularly high. Height growth at 5 years predicted the tallest trees at 10 years (Pearson correlation coefficient $=0.960$ ). Height growth at 10 years (Table 3 ) predicted growth at 23 years
(0.895). Five-year data were not available for determining 23 -year relationships, but one could assume that the correlations would be high. The tallest trees had the largest diameters (correlation $=0.858$ ). The other major variables and the geographic traits did not provide any significantly high correlations to predict growth (Table 3 ).

\section{Regression Analysis}

The reliability of the regression model to predict the 23-year height and diameter from the 10-year data by using a com-

Table 3. Correlations of height and dbh of Rocky Mountain juniper with age and geographic traits.

\begin{tabular}{cllllll}
\hline & $\begin{array}{l}\text { Height at } \\
10 \mathrm{yr}\end{array}$ & $\begin{array}{l}\text { Height at } \\
23 \mathrm{yr}\end{array}$ & $\begin{array}{l}\text { dbh at } \\
23 \mathrm{yr}\end{array}$ & Long. & Lat. & Elev. \\
\hline $\begin{array}{r}\text { Height } \\
5 \mathrm{yr}\end{array}$ & $0.960^{\mathrm{z}}$ & & & & & \\
$10 \mathrm{yr}$ & & 0.895 & 0.909 & 0.267 & -0.144 & 0.175 \\
$23 \mathrm{yr}$ & & & 0.858 & 0.332 & -0.097 & -0.164 \\
& & & & & & \\
dbh 23 yr & 0.858 & & 0.300 & -0.296 & -0.050 \\
\hline
\end{tabular}

${ }^{\mathrm{z}}$ Note: Approximate value from Cunningham and King (2000). 
bination of the geographic variables gave R-square values of 0.3755 (height) and $0.6721(\mathrm{dbh})$ for values significant at the $1 \%$ level. Thus, the height model was weak, but the dbh model was relatively strong. Only longitude squared was significant in the height prediction. Latitude, longitude, elevation, and the squares of longitude and elevation were significant in predicting dbh. Northerly latitudes, easterly longitudes, and elevations lower than those at the Colby site produced larger diameter trees. All but one source came from locations north of Colby.

\section{DISCUSSION AND CONCLUSIONS}

In an earlier study in the Great Plains region (Cunningham and King 2000), Rocky Mountain juniper trees survived better, were shorter, and had smaller crowns than did eastern redcedar (J. virginiana L.) at 10 years of age. Rocky Mountain juniper has better crown compactness for wind reduction than redcedar. In our Kansas study, we found, at 23 years of age that only three seed sources $(4611,4612$, and 5851) had a geographic difference from the others sources compared. They were from southwestern Montana and north central Wyoming and were much shorter in height. These sources are not recommended for windbreak plantings in western Kansas. Thus, the general good health, dense crown, and many stems of Rocky Mountain juniper would provide excellent structure, and this species should be selected for use in establishing new windbreaks in western Kansas and nearby areas in eastern and western Nebraska. Our findings showed growth at 10 years predicted superior growth at 23 years and in agreement with Schaefer (1995) and VanHaverbeke and King (1990) for 5-year and 10-year relationships. Rocky Mountain juniper is prone to Cercospora needle blight in more humid areas of the eastern Great Plains and is not recommended for windbreak plantings in this area.

Acknowledgments. This is Contribution no. 07-69-J from the Kansas Agricultural Experiment Station, Manhattan Kansas.

\section{LITERATURE CITED}

Adams, R.P. 1983. Intraspecific terpenoid variation in Juniperus scopulorum: Evidence for Pleistocene refugia and recolonization in western North America. Taxon 32: 30-46.

Comer, C., R.P. Adams, and D.F. Van Haverbeke. 1982. Intra- and interspecific variation of Juniperus virginia and J. scopulorum seedlings based on volatile oil composition. Biochemical Systematics and Ecology 10:179-306.

Cunningham, R.A., and R.M. King. 2000. Juniper seed sources in the Great Plains. General Technical Report, RMRS-GTR-51. USDA Forest Service, Rocky Mountain Forest Experiment Station. Fort Collins, CO.
Fassett, N.C. 1944. Juniperus virginia, J. horizontalis and J. scopulorum-II. Hybrid swarms of Juniperus virginia and J. scopulorum. Bulletin of the Torrey Botanical Club 71: 475-483.

Harlow, W.M., and E.S. Harrar. 1969. Textbook of Dendrology, 5th Edition, McGraw Hill Book Co., Inc., New York. 542 pp.

Schaefer, P. 1995. Ten-year results of an eastern redcedar and Rocky Mountain juniper provenance test in eastern South Dakota. Northern Journal of Applied Forestry 12:30-35.

Van Haverbeke, D.F. 1968. A population analysis of Junipersus in the Missouri river Basin. New Series 38. Lincoln, NE, University of Nebraska Studies. 82 pp.

Van Haverbeke, D.F., and R.M. King. 1990. Genetic variation in the Great Plains Juniperus. USDA Forest Service. Res. Pap. M-292. Lincoln, NE. 8 pp.

Wayne A. Geyer (corresponding author)

Professor

Forestry Division

Throckmorton Hall

Kansas State University

Manhattan KS 66506, U.S.

wgeyer@ksu.edu

Keith D. Lynch

Associate Professor

Forestry Division

Throckmorton Hall

Kansas State University

Manhattan KS 66506, U.S.

Charles J. Barden

Associate Professor

Forestry Division

Throckmorton Hall

Kansas State University

Manhattan KS 66506, U.S.

Résumé. Trente-six provenances de genévrier des Rocheuses (Juniperus scopulorum Sarg.) ont été plantées dans le cadre d'un test de provenance près de Kolby au Kansas en 1980. La hauteur, le diamètre, le taux de survie, le nombre de tiges, la densité de la cime, l'angle des branches et la vigueur ont été évalués au moyen de techniques d'analyses de variances, d'analyse de grappes, de corrélations simples et d'analyses de régression. Des différences entre les provenances ont été trouvées. La hauteur totale après 23 ans se situait entre 3,6 et 5,4 m, le DHP entre 5,6 et 10,4 cm, et le taux de survie entre 10 et $100 \%$. La croissance en hauteur était faiblement corrélée aux variables géographiques, mais le DHP était relié à la latitude, la longitude et l'élévation. La sélection de provenances à croissance rapide pourrait se faire à compter de la cinquième année après la plantation en plein champs. 
Zusammenfassung. Im jahr 1980 wurden in Colby, Kansas, 26 Quellen für einen Herkunftstest von Wacholder (Juniperus scopulorum Sarg) eingerichtet. Mit ANOVA wurde die Höhe, Durchmesser, Anzahl der Stämme, Astwinkel, Vitalität getestet, eine Cluster-Analyse, simple Korrelation und RegressionsanalysenTechnik. Es wurden Differenzen zwischen den Quellen gefunden. Die totale Höhe im 23. Jahr reichte von 3,6 bis $\mathrm{zu} 5,4 \mathrm{~m}$, der Brusthöhendurchmesser reichte von 5,6 bis $10,4 \mathrm{~cm}$ und die Überlebensrate von 10 bis $100 \%$. Das Höhenwachstum war schwach mit der geografischen Lage verbunden, aber der Brusthöhendurchmesser stand in Beziehung zu Länge, Breite und Höhe. Eine Auswahl der schnellwachsenden Quellen kann ab dem 5. Wachstumsjahr erfolgen.
Resumen. En 1980, se establecieron 26 fuentes de junípero Rocky Mountain (Juniperus scopulorum Sarg.) en una prueba cerca de Colby, Kansas. Se evaluó altura, diámetro, supervivencia, número de tallos, densidad de copa, ángulo de ramas y vigor con técnicas ANOVA, análisis cluster, correlación simple y análisis de regresión. Se encontraron diferencias entre las fuentes. La altura total a 23 años fue de 3.6 a 5.4 m (11.8 a 17.7 pies), el dap (diámetro a la altura del pecho) varió de 5.6 a $10.4 \mathrm{~cm}$. (2.2 a 4.1 pulgadas), y la supervivencia de 10 a $100 \%$. El crecimiento en altura estuvo débilmente relacionado a las variables geográficas, pero el dap estuvo relacionado con latitud, longitud y elevación. La selección de fuentes de rápido crecimiento puede empezar a los cinco años después de la plantación en el campo. 